\title{
Research on the Management of Loss-land Farmers in Tourism Demolition After Moving for Destinations
}

\author{
Yan-fu Tian \\ Silk Road Business School, University of SanYa, Sanya City, China \\ tianyanfu@126.com
}

Keywords: Tourism Development,Tourism Destination,Land-lost Farmers.

\begin{abstract}
With the growth trend of leisure tourism, the tourism destination development goes to the depth and width. Problems protrude gradually, caused by the governmental management concerning compensation and follow-up management upon the native settlers in the tourism development areas. The tourism demolition's effects on the farmers actually go upon their lands and residing resources in which farmer exchange once and for all with cashing and housing. Parts of farmers who are not good at investing, return back to the poor state after they spend all their money out, which lay the potential problems for great social dangers. This research takes the form of questionnaire to study on the follow-up management of the native farmers in the tourism development area. The finding stands at that the farmers are mostly lack of legal awareness, strong desire to spend the compensation fee, weak desire to start up their business, but great need of various training. The research offers the suggestion that the government may offer the purposeful training in terms of financial and professional capability.
\end{abstract}

\section{Introduction}

In recent years, with the continuous development of China's economy, people's income levels continue to rise up and they require for higher quality of life. In order to meet their needs, lots of new destinations for holiday tourism and vacation have been constructed. Vacation travel is characterized by that tourists stay in a place longer than the traditional tourists. Because tourists from the cities get tired of the noisy and impetuous metropolis life, yearn for the country's quietness and simplicity in order to get fresh physically and spiritually, the towns with the elegant environment and distinctive style has become their first choice for holiday leisure. Especially following the progress of network and communication technology, and the convenience of traveling by autos, etc., the independent travel has become the main alternation of city tourists. They want to experience different cultural tastes and services with a higher quality, more preferable to the small town with popular ecological environment, rich and distinctive style. Furthermore, this trend drives the development of urbanization into the fast lane. On the national level, the overall plannings of city and rural development speed up the constructions of beautiful village and town.

The national measures to encourage the development of tourism have promoted the boom of tourism destination construction around the country. Many locations with marvelous mountains, water, scenery have been cultivated as pioneers in the local tourism development. Meanwhile, it has greatly promoted the construction of such tourist facilities as provincial tourism hotels, tourist attractions and customs town, etc., and overall the development of tourism industry. But behind the heat of tourism development, is the vast landless peasants livelihood problems, "urbanization of farmers" problem. This paper will study the causes of this phenomenon and the countermeasures to solve the problem, and will provide suggestions for policy-makers.

\section{Literature Review}

$\mathrm{Xu}$ wei, liu jiabin point out that the issue of compensate are involved in the core interests of squatter settlement' resident in the process of Squatter Settlement' renovation, and they established three model such as totally reconstruction, portion reconstruction or protecting portion 
reconstruction,and established a system to accomplish the resettlement compensation[1]. Some local governments take it for granted that "I expropriated your land, I paid you a compensation fee; I used your house, I built a commercial housing for you."From the materialistic point of view, by demolition, the landless peasants change from the former "poor" with no money into the present "rich" with a large amount of cash; live from in the low houses into a bright and spacious commercial housing, and in some places, even resettlement housing is even built with the standard and style of the tourism destination; so accordingly, the quality of life of farmers in demolition area should be greatly improved, how will there be landless peasant livelihood problems? But the emergence of the phenomenon of landless peasants poverty takes the problem to the front desk. The landless farmers return to the poverty after spending the huge amount of cash, and they are still the object of government poverty alleviation.How should the Government help the poor of this type?

Sustainable livelihood Analysis has been a new research method for sustainable development and a framework to analyze the complex and multi-dimensional relationship between social and physic al environment[2]. The model has been used by Zuo Bing, Chen Weibo to analyze the impact on the livelihoods of relocated residents. The study thus advocates the government to establish effect ive public training programme and psychological intervene mechanism for relocated people to help them improve human capital[3].

\section{Methodology}

This study takes the methods of a questionnaire survey and interviews to the people in a tourist relocation area. The survey content goes around the changes in the lifestyles they faced after the relocation, how to deal with the problems such as how to deal with the compensation fee and change of production mode, and the focus goes on the investigation and in-depth interviews upon the residents who have been moved in. A total of 200 questionnaires were distributed, and 200 valid questionnaires were collected, among which, 105 were male, accounting for 52\%; 95 were female, accounting for $48 \%$.

\section{Survey Analysis}

Analysis result shows that the living condition after moving into the resettlement area improves greatly, with living space great and bright, living town clean and tidy, and the streets and other public area are served and maintained by the professional property management company. The resettled households are supplied with modern facilities, such as color TV, refrigerator. 55\% of resettled families regard that the gas line has been improved, $44 \%$ regard that the water supply has been improved and 22\% regard that the cable TV system has been improved. The living quality has been raised in comparison with the life in the countryside before resettlement. Anyhow the problems revealed in the investigation are still to be considered seriously as follows.

\subsection{Legal awareness is weak}

In the item of farmers in a conflict of interest, whether they will choose to use legal means to protect their own interests, up to $56 \%$ of the farmers choose that they will not take legal means, $10 \%$ choose that it does not matter, only $34 \%$ of people think that they will take legal means to maintain their own interests. It can be seen that majority of farmers the legal awareness is weak, it means they do not know how to use legal means. In modern urban civilization, citizens are not familiar with each other, so the means to deal with disputes is mainly the law, the public use the legal weapons to protect their rights. The farmers' common habit of dealing with the disputes is that of the family awareness, violence upon violence, tooth upon tooth, which needs change to legalization, to take the law as the yardstick to deal with different interests.

\section{2 strong desire to waste the compensation money}

In the item of "how to deal with resettlement fee", farmers of different gender and age groups reflect vast deviation. The male choice of "The use of the resettlement fee" is more concentrated on 
direct consumption (92\%), followed by investment and financial management (80\%) and self-employment (74\%). Among them, people under 35 years mainly propose the investment and financial management, self-entrepreneurship; those of 35-45 years mainly focus on the direct consumption, investment and financial management; those of over 45 years old mainly focus on the direct consumption and savings. For women, the use of resettlement fee is more concerned with the prevention of risk, and the expenditure plan is more conservative, mainly concentrated in savings (95\%), children's education (94\%) and direct consumption (65\%).

In the survey, up to $92 \%$ of men had direct consumption desire. The adult males take in charge the family, and they got the power over compensation money spending, although $95 \%$ of women have a propensity of bank saving, but they have no control over the consumption impulse of adult males, which will inevitably lead to a lot of waste. The irrational consumption of the valuable capital is not conducive to the formation of entrepreneurial atmosphere, and also a huge obstacle to the follow-up sustainable development of the family.

\section{3 weak desire for entrepreneurship}

$50 \%$ of men are willing to go to work, $31 \%$ of men want to start their own businesses, $19 \%$ of men do not want to do things; Up to $88 \%$ of women are willing to go to work, $9 \%$ of women do not want to do things, there are only $2 \%$ of entrepreneurial thinking.

One of the important issues reflected in the survey is that the entrepreneurial atmosphere of farmers is weak and entrepreneurial intentions are not strong. Only $31 \%$ of men and $2 \%$ of women have entrepreneurial awareness. The proportion of men entrepreneurship is much higher than the female, and the current majority of families is the men to master the financial power. They have not urgent intentions to use the existing assets for business. In addition, up to $88 \%$ of women and $50 \%$ of men want to find a job, they have been engaged in agricultural production, most people lack of the skills and knowledge on the business, short board seriously restricts their development. In order to enhance their capability to business, it is needed to provide the high-intensity professional training and practical training and other means.

\subsection{Great Need of Various Training}

The survey found that up to $73 \%$ of the farmers were willing to participate in the training, $27 \%$ want to see the situation and then take the action. Between the participation, $46 \%$ said they wanted to take part in the train focusing on investment and financial management, $27 \%$ said they wanted to take part in the job skills training. Mean time, some of them want to participate in entrepreneurship training. The diversity of training needs reflects their clear orientation of future occupations.

Up to two-thirds of the people desire for investment training and entrepreneurship training, this illustrates the farmers who use their own land assets in exchange for the "cash assets", they want to know how to use the special cash assets, this kinds of knowledge and skills needed to learn; also reflects the fact that they have a lot of cash on hand, they want to transition their lifestyle from agriculture to business.

\section{Conclusion}

According to the investigation, it is clearly that most of farmers know how to work in agriculture, but they do not know how to work in business. For the money, it is more easy to spend then to earn. They got the desire to spend, they want to show that they have changed status from poor to rich. Without the control, the cash will be spent out quickly. Without the capacity to earn money on the money, it is not sustainable for them to stay there long term. In response to the problem of returning poverty, the strategy to deal with the problem should be that the government should provide the farmer with the capability to manage the finance and operation, to match their new resources. After the farmer lost their land, the previous way of production and life was unsustainable, they need the new technologies and skills to achieve the transformation of production methods. the current academic solution to the problem is the training. Most important, farmers want to participate the 
train. Through professional skill trains, so that they can master the new investment and other professional skills, in order to achieve entrepreneurship and employment. Through the training of legal knowledge to develop their legal awareness.

\section{Acknowledgement}

In this paper, the research was supported by team members Mr.Liu Peng, Ms.Li Ailin.

\section{References}

[1] Xu wei, liu jiabin. Analysis on Compensation for Resettlement and Resettlement in Urban Shanty Area. Journal of Inner Mongolia University of Technology[J]. 201736 (1) 57-63.

[2] Su Fang, Xu Zhongmin, Shang Haiyang.An Overview of Sustainable Livelihoods Approach. Advances in Earth Sciences[J]. 200924 (1) 61-69.

[3] Zuo Bing,Chen Weibo.Impacts of Tourist Resorts Development on the Sustainable Livelihoods of Relocated Residents:A Case Study of Chimelong International Ocean Tourist Resort. Tropical Geography[J]. 201636 (5) 776-785. 